\title{
Surgical outcome of scoliosis in Marfan syndrome: a case series report
}

\author{
Komang Agung Irianto S*, Gestana R Wardana \\ Department of Orthopaedic and Traumatology, Airlangga University / Dr. Soetomo \\ General Hospital Surabaya
}

DOI: http://dx.doi.org/10.19106/JMedSci005002201814

\begin{abstract}
Scoliosis in marfan syndrome (MFS) manifests on $60 \%$ patients. Moreover, the scoliosis noticeable in earlier age is more progressive, refracted, and rigid compared to idiopathic adult scoliosis. The surgical correction provides notorious higher perioperative risk, whereas conservative treatment using brace is not effective to prevent progressivity of the scoliosis. In this a case report, we reported the surgical outcome of MFS scoliais patients with MFS who operated using posterior fusion instrumentation by mean of the quality of life SF-36 questioner. This was a retrospective case series involving five MFS scoliosis patients who underwent posterior fusion instrumentation with initial Cobb angle of $87.417 .57^{\circ}$ and initial kyphotic angle of $32.8 \pm 14.52^{\circ}$. Clinical, radiological and quality of life of the patients based on SF-36 questionnaire were evaluated within 6-36 months follow up. Post-operative showed the Cobb angle become $46.2 \pm 16.3^{\circ}$ and the kyphotic angle become $21.6 \pm 9.94^{\circ}$. No intraoperative or post-operative complications were observed. After 6-36 months follow up, the Cobb angle became $45.2 \pm 17.48^{\circ}$ and the kyphotic angle became $21.6 \pm 9.94^{\circ}$. In addition, all patients had physical and mental health scored similar to 2 years post-surgery scoliosis scoring according to SF36 orthopedic scoring guidelines. I conclusion, the surgical outcome of posterior fusion instrumentation in MFS scoliosis showed good correction of Cobb angle and Kyphotic angle. The quality of life of the patients based on physical and mental health questionnaire is satisfactory.
\end{abstract}

\section{ABSTRAK}

Skoliasis diderita pada $60 \%$ penderita sindrom Marfan (SM). Selain itu, skoliasis yang diderita sejak usia muda lebih progresif, bias dan kaku dibandngkan dengan skoliais dewasa idiopatik. Penatalaksanaan melalui tindakan bedah memberikan risiko perioperative lebih tinggi, sedangkan penatalksanaan konservatif dengan penjepitan tidak efektif untuk mencegah progresivitasnya. Dalam laporan kasus ini disampaikan luaran tindakan bedah pasien SM dengan skoliais dan kualitas hidupnya berdasarkan pertanyaan dalam SF-36 setelah dilakukan tindakan dengan peralatan fusi posterior. Loran kasus serial retrospektif ini melibatkan lima penerita skoliosis dengan SM yang menjalani instrumentasi fusi posterior sudut Cobb awal $87,4 \pm 17,57^{\circ}$ dan sudut kifotic awal $32,8 \pm 14,52^{\circ}$. Kondisi klinik, hasil pemeriksaan radiologi dan kualitas hidup berdasarkan kuisionair SF-36 dievaluasi selama pengamatan 6-36 bulan. Pasca operasi menunjukkan sudut Cobb menjadi 46,2 \pm $16,30^{\circ}$ dan sudut kifotik menjadi $21,6 \pm 9,94^{\circ}$. Tidak dijumpai komplikasi intraoperasi dan pasca operasi selama pengamatan. Setelah dilakukan pengamatan selama 6-36 bulan, sudut Cobb menjadi 45,2 $\pm 17,48^{\circ}$ dan sudut kifotik menjadi $21,6 \pm 9,94^{\circ}$. Semua pasien mempunyai skor kesehatan fisik dan mental sama dengan skor skolastis setelah 2

\footnotetext{
* corresponding author : komang168@yahoo.com
} 
tahun pasca operasi menurut petunjuk penilaian oropedi SF-36. Dapa disimpulkan luaran bedah instrumentasi fusi posterior pada pasien scoliosis dengan SM menunjukkan koreksi yang baik terhadap suduk Cobb dan kifotik. Kualitas hidup pasien berdasarkan kuisionair kesehatan fisik dan mental memuaskan.

Keywords: scoliosis - Marfan syndrome - quality of life - questionnaire SF-36 - Cobb angle

\section{INTRODUCTION}

Marfan syndrome (MFS) is one of multi systemically disorder caused by generalized collagen abnormality (FBN1; fibrillin-1) that is inherited in autosomal dominant. ${ }^{1,2}$ Other than the excessive longitudinal growth on growth plate cartilage (hyperchondroplasia), thin and long extremity seen as spider-like finger (arachnodactyly); the tangible sign are the facial features (dolichocephalic, enophthalmos, down slanting palpebral fissures, malar hypoplasia, retrognathia), and chest asymmetry (pectus excavatum/ carinatum). ${ }^{3,4}$ The condition is somehow stigmatism, hamper the life insurance opportunity, as well as the psychosocial burden $^{2}$. The diagnosis criteria have been revised for the purposes not to over diagnosed or under diagnosed it. ${ }^{2,3}$ Genetic evaluation is not the only diagnosis tool, yet other ancillary technique is not always available and feasible for our community.

The undetected dilatation of aortic base such as aneurysm of ascending aorta might complicate the scoliosis surgery or the other way the abnormal thoracic cage would complicate the cardiac and pulmonary condition which could happened later in young adult age. ${ }^{1,2,3,4}$ The main management for Marfan syndrome depends on which chief organ system involved. ${ }^{3,4,8,9}$ Scoliosis prevalence in this syndrome is around $60 \%$. Scoliosis in MFS usually occur and being noticeable at younger age, more progressive, refractory, and rigid. It is also the main complaint of back pain in the later age. ${ }^{5,6,7}$

In common community, scoliosis is the disease, not just the symptom. Very seldom the underlying cause was investigated. In our former study in screening the junior high school student in Surabaya, 2.7\% students indicate scoliosis and 3 neglected cases were found. ${ }^{10}$ Most of the cases are adolescent idiopathic scoliosis (AIS); which surgery is performed when the cobb angel is more than $40^{\circ}$. But in MFS the early onset and progressive scoliosis is the problem to be solved. ${ }^{3,4,5}$ The use of brace in conservative treatment is not effective for preventing the progressivity of the scoliosis. ${ }^{5}$ Surgery by posterior fusion instrumentation is one of the technique for scoliosis correction nevertheless the collagen abnormality and anatomical deformity in MFS might complicate the perioperative risk and the correction result. ${ }^{7,11,12}$ The purpose of this study is to evaluate the surgical outcome not only the correction by clinical and radiology but also by using SF-36 questionnaires to value the physical and mental health of the MFS patient.

\section{CASE REPORT}

This is a descriptive retrospective study of case series. The research protocol was approved by institutional ethics and review board in both 2 hospitals, Dr Soetomo General Hospital Surabaya and Surabaya Orthopedic \& Traumatology Hospital. Five MFS patients with scoliosis were underwent corrective 
surgery using posterior fusion instrumentation according to standardized department protocol during 2014 to 2016. All patients were managed by a single orthopedic surgeon, same instrument, and same management protocol. The MFS was diagnosed based on Revised Ghent criteria. ${ }^{2}$ The pre-operative management was incorporating cardiac evaluation, ophthalmology evaluation, and MRI ofthe spine to evaluate the dural ectasia. None of the patients had aortic root aneurysm, ectopia lentis, or family history. But 4 out of 5 had thick myopia, the facial features, and $>7 / 20$ systemic features involvement. ${ }^{2}$ Database of initial patient condition were recorded from medical record, including the demographic data, clinical and radio imaging data. Pre and post Cobb angel and Kyphotic angel were compared to the follow-up measurement. The SF-36 questionnaire was performed by interviewing the patient on the follow up visit. Follow up was 6-36 months.

\section{RESULTS}

The 5 MFS patients were all female with the age range of $11-17$ years (:13.6 years) at surgery; $13-18$ years (:15.6 years) at the follow up, and all were without cardiac or respiratory abnormalities. All of them were came when the Cobb angel were $>70^{\circ} ; 2$ of them were $>100^{\circ}$ and 2 patients of double curves (RTLL). The mean Cobb angel before surgery was $(87.4 \pm 17.5)^{\circ}$. The initial kyphotic angel was $(32.8 \pm 14.5)^{\circ}$. The degree of correction directly post-surgery was $(41.2 \pm 1.78)^{\circ}$ and $(16.8 \pm 9.83)^{\circ}$ respectively. The number of the segment fusion were 15(Th2-L4) - 17(Th1-L5) segments. After surgery all patients were immobilized with brace for 3-6 months.

The length of the surgery averaged (322 \pm 38.3$)$ minutes (range:270-370 minutes). The average blood loss was $(495 \pm 44.7)$ cc (range: 450-550 cc). There was absent of surgical complication during and after the surgery. On Follow-up after 6 - 36 months, there were almost no scoliosis nor kyphotic progression in all patients. The physical health status and mental health status from SF-36 questionnaire were good with the average of PHS 48.4 and MHS 49.

TABLE 1. Clinical, radiology, correction, and quality of life (SF-36) in Scoliosis Marfan syndrome patients

\begin{tabular}{|c|c|c|c|c|c|c|c|c|c|c|c|c|c|c|}
\hline \multirow{2}{*}{ Patient } & \multirow{2}{*}{ Sex } & \multirow{2}{*}{$\begin{array}{c}\text { Age } \\
\text { (years) }\end{array}$} & \multirow{2}{*}{$\begin{array}{c}\text { Curve } \\
\text { pattern }\end{array}$} & \multirow{2}{*}{$\begin{array}{c}\text { Fusion } \\
\text { Level }\end{array}$} & \multicolumn{3}{|c|}{$\begin{array}{c}\text { Cobb angle } \\
\left({ }^{\circ}\right)\end{array}$} & \multicolumn{3}{|c|}{$\begin{array}{c}\text { Kyphotic angle } \\
\left({ }^{\circ}\right)\end{array}$} & \multirow{2}{*}{$\begin{array}{c}\text { Op } \\
\text { time } \\
\text { (min) }\end{array}$} & \multirow{2}{*}{$\begin{array}{c}\text { Blood } \\
\text { Loss } \\
\text { (cc) }\end{array}$} & \multicolumn{2}{|c|}{ SF-36 score } \\
\hline & & & & & $\begin{array}{c}\text { Pre- } \\
\text { op }\end{array}$ & $\begin{array}{c}\text { Post } \\
\text { op }\end{array}$ & $\mathbf{F U}$ & $\begin{array}{c}\text { Pre- } \\
\text { op }\end{array}$ & $\begin{array}{l}\text { Post } \\
\text { op }\end{array}$ & $\mathbf{F U}$ & & & PHS & MHS \\
\hline 1 & $\mathrm{~F}$ & 18 & RTL & T2-L5 & 102 & 58 & 58 & 45 & 16 & 16 & 340 & 500 & 45 & 55 \\
\hline 2 & $\mathrm{~F}$ & 16 & RT & T2-L4 & 70 & 30 & 25 & 38 & 32 & 32 & 270 & 450 & 55 & 46 \\
\hline 3 & $\mathrm{~F}$ & 18 & RT-LL & T1-L4 & $80 / 68$ & $40 / 32$ & $40 / 32$ & 8 & 22 & 22 & 330 & 550 & 42 & 48 \\
\hline 4 & $\mathrm{~F}$ & 13 & RT & T1-L4 & 110 & 68 & 68 & 33 & 8 & 8 & 300 & 450 & 47 & 50 \\
\hline 5 & $\mathrm{~F}$ & 13 & RT-LL & T1-L5 & $75 / 55$ & $35 / 20$ & $35 / 20$ & 40 & 30 & 30 & 370 & 525 & 53 & 46 \\
\hline
\end{tabular}

RTL: right thoraco-lumbal; RT: right thoracal; RT-LL: right thoracal-left lumbal; Pre-op: preoperative; Post op: postoperative; Op time: operative time; FU: follow up (6-36 months); PHS: Physical Health Status; MHS: Mental Health Status 

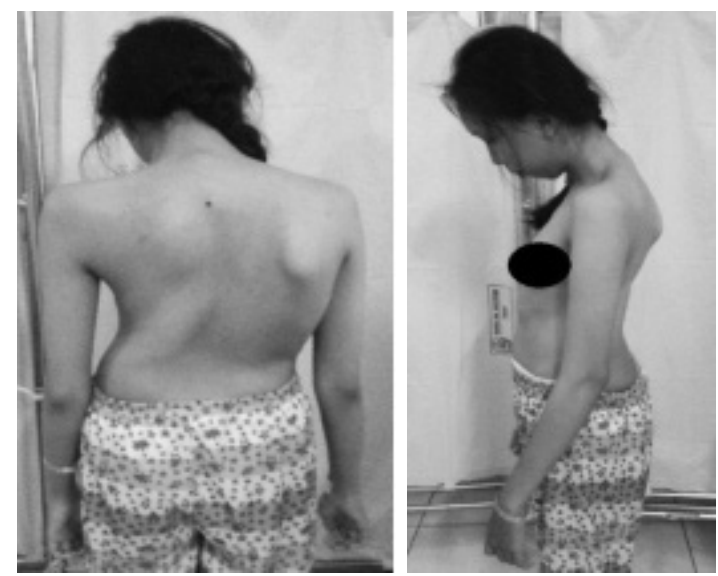

(A)
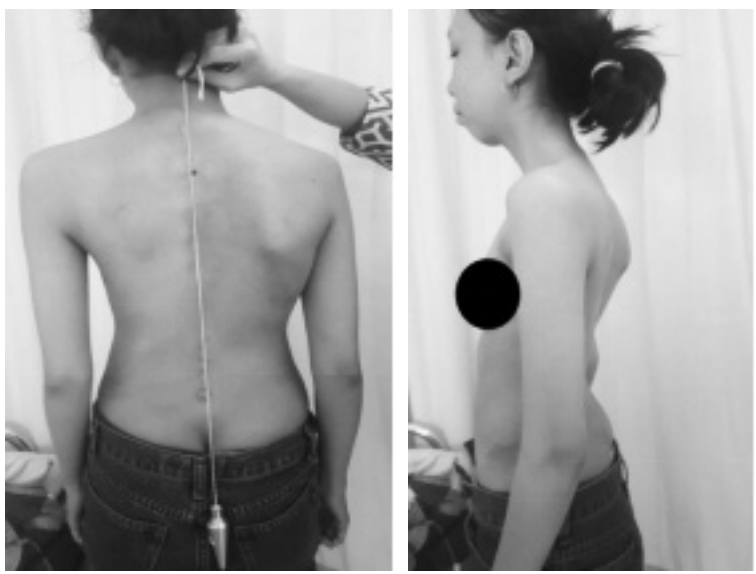

(B)

FIGURE 1. Clinical appearance 18 years female with RT-LL curve treated with posterior fusion instrumentation, (a) initial pre-operative, (b) follow up post-operative after 1 year

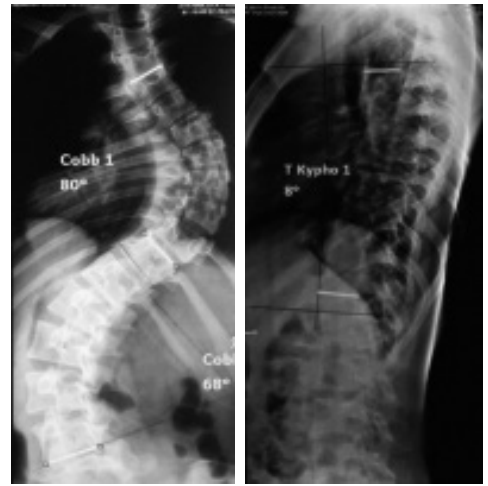

(A)

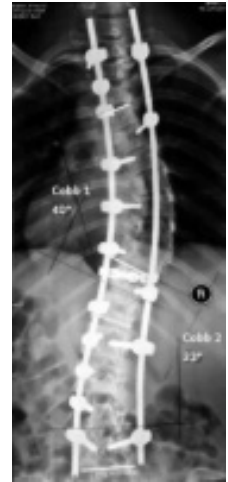

(B)

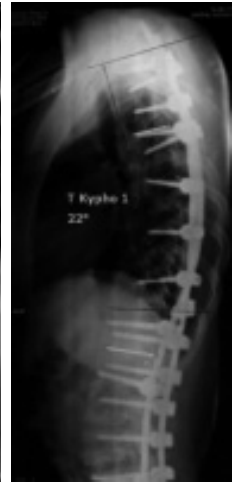

)
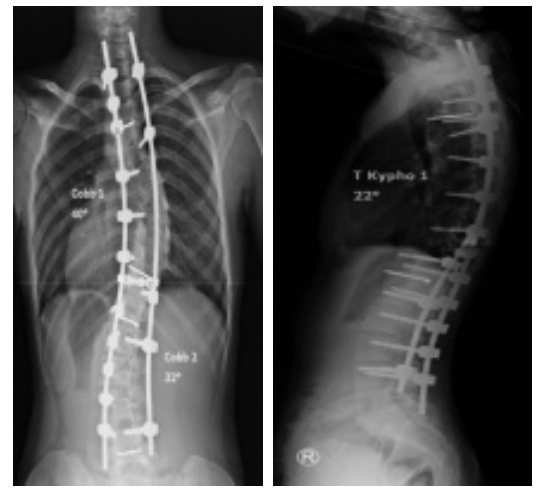

(C)

FIGURE 2. Radiological imaging of 18 years female with RT-LL curve treated with posterior fusion instrumentation, (a) pre-operative, (b) post-operative, (c) follow up after 1 year

\section{DISCUSSION}

In this study the surgical outcome is not only about the physical outcome (cobb angel and kyphotic angel) but also about the quality of life. Since the main complaint from the patient's site is the body contour, the selfesteem confident is also considered as one of the surgical outcome. The SF-36 do not have the cut-off point for good or bad result. ${ }^{13}$ The SF-36 forms have been used often in examining orthopaedic patient populations. The brief guide from Various Orthopaedic Procedures and Conditions comparing SF-36 pre and post-surgery reported similar result of scoliosis patient, $\mathrm{PH} 42.2$ to 46.4 and $\mathrm{MH}$ 48.9 to $50.6 .^{14}$

Surgical outcome of a reconstruction surgery is usually concern for degree of correction. The degree of correction of the cobb angel (40-44) ${ }^{\circ}$ and kyphotic angel (6-29) ${ }^{\circ}$ were comparable to study reported by Zenner et.al when using posterior spinal fusion only $\left(44^{\circ}\right)$ yet less than when using combine PSF and Anterior $\left(57^{\circ}\right) .{ }^{11}$ Nonetheless blood loss and time of surgery were better in posterior spinal fusion only. ${ }^{6,7,11,12}$ When comparing with surgery of AIS, the correction, blood loss, and time of surgery were similar and not significant. ${ }^{6,15}$ 
Surgical therapy is an effective choice of therapy for scoliosis in Marfan syndrome, bracing has been proven only success in $17 \%$ cases but eventually those cases need surgery as well, owing to the progressing curve..$^{5,711,12}$ The use of growing rod is a good choice, anterior release is not necessary if surgery was not postponed; when the curve has progressed rapidly which is the notorious problem in MFS. ${ }^{67,11}$ Hook is not advisable due to the underlying desmogenic disorder. Before surgery MRI should be assessed for possible dural ectasia, pedicle thinning, and dysplastic lamina. ${ }^{15}$

The surgery must cover all the major curve including pelvis fusion involvement when necessary to avoid the re-surgery. ${ }^{11,12,15} \mathrm{We}$ fused 15-17 level and after up to 3 years follow up the progression was none to minimal $\left(5^{\circ}\right)$ in one case. The invention of pedicle screws gives important progression in scoliosis correction. Pedicle screws, using the strongest part of vertebral body as an anchor, provide the spine surgeon with an enhanced three-dimensional deformity correction. Pedicle screws that placed in the vertebral body have $30 \%$ greater moment arm for applying corrective forces than posterior hooks. Posterior segmental instrumentation with a powerful pedicle screw anchor offers satisfactory correction without significant loss of curve correction even in severe deformity cases. ${ }^{12}$ Posterior fusion with instrumentation has been widely used for the surgical treatment of scoliosis in the Marfan syndrome, particularly in the curves ranging beyond $40^{\circ}-50^{\circ}$ that tend to progress more after skeletal maturation. ${ }^{7,12}$

This study need to be continued with larger samples and multicenter to give orthopedic surgeons precise and merit planning in surgical management of scoliosis in MFS. Scoliosis in MFS would not be too complicated if planned in the current knowledge of underlying the multi systemically disorder as MFS.

\section{CONCLUSION}

The surgical outcome of posterior fusion instrumentation in MFS scoliosis shows good Cobb angle and Kyphotic angle correction. The blood loss, time of surgery, and surgical complication is all satisfying and comparable to other study with larger samples. The quality of life of the patients based on physical and mental health questionnaire (SF-36) is similar to other various orthopedic procedure and condition.

\section{ACKNOWLEDGEMENTS}

We would like to thank all patients who involved in this study.

\section{REFERENCE}

1. Herring, JA. Tachdjian's Pediatric Orthopaedics $5^{\text {th }}$ Edition. Philadelphia: Saunders Elsevier; 2012

2. Loeys BL, Dietz HC, Braverman AC, Callewart BL, de Backer J, Devereux RB, Hilhorst-Hofstee Y., Jondeau G., Faivre L., Milewicz DM., Pyeritz RE., Sponseller PD., Wordsworth P., Paepe AM. The Revised Ghent Nosology for the Marfan Syndrome. $J$ Med Genet 2010; 47(7):476-85. https://doi.org/10.1136/jmg.2009.072785

3. Sponseller PD, Erkula G, Skolasky RL, Venuti KD, Dietz HC. Improving Clinical Recognition of Marfan Syndrome. J Bone Joint Surg Am 2010;92(9):1868-75. https://doi.org/10.2106/JBJS.I.00892

4. Dean JCS. Marfan Syndrome: Clinical Diagnosis and Management. Eur J Hum Genet 2007; 15(7):724-33. https://doi.org/10.1038/sj.ejhg.5201851

5. Sponseller PD, Bhimani M, Solacoff D, Dormans JP. Results of Brace Treatment of Scolosis in Marfan Syndrome. Spine 2000; 25(18):2350-4. 
https://doi.org/10.1097/00007632200009150-00013

6. Liang $\mathrm{W}, \mathrm{Yu} \mathrm{B}$, Wang $\mathrm{Y}$, Li Z, Qiu G, Shen J, Zhang Jianguo. Comparison of Posterior Correction Results Between Marfan Syndrome Scoliosis and Adolescent Idiopathic Scoliosis-a Retrospective Caseseries Study. J Orthop Surg Res 2015; 10:73. https://doi.org/10.1186/s13018-015-0210-Z

7. Qiao J, Xu L, Liu Z, Zhu F, Qian B, Sun Xu, Zhu Zezhang, Qiu Yong, Jiang Qing. Surgical Treatment of Scoliosis in Marfan Syndrome: Outcome and Complications. Eur Spine J 2016; 25(10):3288-93. https://doi.org/10.1007/s00586-016-4579-0

8. Tinkle BT, Saal HM. Health Supervision for Children with Marfan Syndrome. Pediatrics 2013; 132(4):1059-72. https://doi.org/10.1542/peds.2013-2063

9. Pyerit RE. Evaluation of the Adolescent or Adult with Some Features of Marfan Syndromes. Genet Med 2012; 14(1):171-7. https://doi.org/10.1038/gim.2011.48

10. Komang Agung IS, Dwi Purnomo SB, Susilowati A. Prevalence Rate of Adolescense Idiopathic Scoliosis; Result of School base Screening in Surabaya, Indonesia. Malaysian Orthopaedic Journal 2017;11(3):17-21 https://doi.org/10.5704/MOJ.1711.011

11. Zenner J, Hitzl W, Meier O, Auffarth A, Koller H. Surgical Outcomes of Scoliosis Surgery in Marfan Syndrome. J Spinal Disord Tech 2014; 27(1):48-58.

h t t p s : //doi .org / $10.1097 /$ BSD.0b013e31824de6f1

12. Li ZC, Liu ZD, Dai LY.Surgical Treatment of Scoliosis Associated with Marfan Syndrome by Using Postorior-only Instrumentation. $J$ Pediatr Orthop B 2011; 20(2):63-6.

h t t p s : // d o i . org / $10.1097 /$ BPB.0b013e328341bcc9

13. McHorney CA, Ware JE, Lu JFR, Sherbourne CD. The MOS 36-Item Short-Form Health Across Diverse Patient Groups. Med Care 1994; 32(4): 40-66.

https://doi.org/10.1097/00005650199401000-00004

14. Laucis Nicholas C., Hays Ron D., Bhattacharyya T. Scoring the SF-36 in Orthopaedics. A Brief Guide. J.Bone Joint Surg Am. 2015 Oct 7;97(19): 1628-1634. https://doi.org/10.2106/JBJS.O.00030

15. Gjolaj JP, Sponseller PD, Shah SA, Newton PO, Flynn JM, Neubauer PR, Marks M., Bastrom TP. Spinal Deformity Correction in Marfan Syndrome Versus Adolescent Idiopathic Scoliosis: Learning from the Differences. Spine 2012; 37(18):1558-65.

h t t p s : // d o i . org/10.1097/ BRS.0b013e3182541af3 